\begin{tabular}{|c|c|c|}
\hline $\begin{array}{c}\text { PORT SAID ENGINEERING RESEARCH JOURNAL } \\
\text { Port Said University - Faculty of Engineering } \\
\text { Volume 16 No. 1 pp: 52:61 }\end{array}$ & \\
\hline
\end{tabular}

\title{
Enhancement of the performance of a split-air-conditioner by cooling the condenser using the evaporative condensate
}

\author{
K.A. Morad ${ }^{1}$, E.I. Eid ${ }^{2}$, M. Abdel-Halim ${ }^{2}$ and M.T. Tolan ${ }^{2}$
}

\begin{abstract}
This work is concerned with an experimental investigation for the performance of a split-air- conditioner when cooling its condenser using its evaporative condensate. The evaporative condensate was collected in a water basin located above the condenser. The collected condensate flows past the condenser through a number of holes in basin base. The experimental tests were investigated during the day time in Suez city, EGYPT, under different relative humidity. The condenser is an air forced one. Its design is L-shaped; the pipe diameter of the condenser is $7.0 \mathrm{~mm}$, material: (inner groove copper tube aluminum fins). It has twin rows with sixteen fins per inch. The outer dimensions of the condenser are $0.85 \mathrm{~m}$ length, $0.15 \mathrm{~m}$ width and $0.7 \mathrm{~m}$ height. The experimental results showed that the power consumption can be decreased by about (12.1: $20.9 \%)$ and the coefficient of performance can be increased by about (16.24: 29.50\%) according to ambient conditions.
\end{abstract}

KEYWORDS: Air conditioner, evaporative condensate, split, energy saving, coefficient of performance.

\section{NOMENCLATURES}

\begin{tabular}{|c|c|c|c|}
\hline SYMBOL & DESCRIPTION & $\underline{\text { UNIT }}$ & $a$ \\
\hline$C O P$ & $\begin{array}{l}\text { Coefficient of } \\
\text { performance }\end{array}$ & & $\begin{array}{l}a m b \\
c a p\end{array}$ \\
\hline $\mathrm{i}$ & Electric current & Amp & comp \\
\hline$p$ & Pressure & $N / m^{2}$ & cond \\
\hline$q$ & $\begin{array}{l}\text { Heat added or } \\
\text { removed }\end{array}$ & $k J / k g$ & \\
\hline$T$ & Temperature & ${ }^{0} \mathrm{C}$ & evap \\
\hline$w$ & Work & $k J / k g$ & $i$ \\
\hline$\phi$ & Humidity ratio & & $w b$ \\
\hline$\xi$ & $\begin{array}{l}\text { Enhancement } \\
\text { factor }\end{array}$ & & \\
\hline
\end{tabular}

\section{Subscripts}

$\begin{array}{ll}a & \text { Air } \\ \text { amb } & \text { Ambient } \\ \text { cap } & \text { Capillary } \\ \text { comp } & \text { Compressor } \\ \text { cond } & \text { Condenser } \\ d b & \text { Dry bulb } \\ e & \text { Exit } \\ \text { evap } & \text { Evaporator } \\ i & \text { Inlet } \\ w b & \text { Wet bulb }\end{array}$

\section{Introduction}

The technological progress in air conditioning equipment increases the demand for this equipment especially in the hottest and coldest zones. More than $40 \%$ of the total energy consumption is used to cover the demand of the heating and cooling.

1. Mech. Power Dept. Faculty of Enging, Port-Said University, PortSaid, Egypt.

2. Mech. Dept. Faculty of Ind. Edu, Suez Canal University, Suez, Egypt.

Depending on the climate, the energy bill could be dominated by cooling in summer and heating in winter. Decreasing energy consumption by renewable energy is an important task for decreasing global warming. Residential vapor compression units are widely spread all over the world. Recently the air conditioning units that were used widely in the public offices, houses and markets in dry and desert cities; are especially equipped with air condensers and evaporators that are using dry air in the heat transfer processes like that windows and split units. Although these units have a good coefficient of performance, $C O P$, one can go through the increase of 
$C O P$ by trying to make the operation of the condensation process to be wet instead of dry. Condensation process involves three type; air-cooled condenser for residential appliance, air-water condenser for large markets appliance and evaporative condenser for non-residential appliance. The popular design for an evaporative condenser includes a spray of water falling onto the condenser tubes as air is simultaneously blown over the tubes. For the first one; the higher airflow rates the more effective condensations. For the second one; the existence of water beside air makes more effective contestation. In general, one can say; the energy consumption of the conditioning units depends on the $C O P$, which is improved by decreasing the condensing temperature. The $C O P$ of the refrigerating systems with air-cooled condenser drops down when the ambient air temperature increases especially in hot regions in summer. This will motivate the target of present work, as its aim is to reduce the condenser temperate, which hopefully increases $C O P$.

Some modifications on window air conditioner unit by adding water circuit spryer on the condenser tubes to reduce the pressure and temperature were made by Ref. [1]. The results achieved reduction in the power consumed by $16 \%$ and an enhancement in COP by 55\%. A combined system consists of two or three evaporators, one or two of them were water evaporative cooler and one refrigerant evaporator was suggested by Ref. [2]. The system is able to reduce the air temperature by $15{ }^{\circ} \mathrm{C}$ below the outdoor temperature. The evaporative condenser with water sprayers on the condenser tubes was studied Ref. [3]. The idea has some disadvantage like growth of the frost thickness evaporator coils and water pool poses a health hazard as biological growth such as legion of fungous may develop. An optimized refrigeration system utilizing a combination of single screw and reciprocating compressors, evaporative condenser and combination of liquid overfeed and direct expansion evaporators was suggested by Ref. [4]. A reduction in annual energy consumption of $11 \%$ had been achieved. An innovative, evaporative condenser for residential refrigerator was studied experimentally by Ref. [5]. The results showed that the condenser temperature increases by $0.45{ }^{0} \mathrm{C}$ for each degree increase in evaporator temperature. A simplified mathematical model was developed to describe the heat, moisture transfer between water and air in a direct evaporative cooler studied by [6]. The predicted results showed the direct evaporative cooler with high performance pad material to be may be well applied for air conditioning with reasonable choices for the inlet frontal velocity and pad thickness. A model-based optimization strategy for the condenser water loop of centralized heating, ventilation and air conditioning (HVAC) systems was studied [7]. The experimental results on a centralized HVAC pilot plant showed that the operating cost of the condenser water loop can be substantially reduced compared with conventional operation strategies. The COP of the chillers can be improved by a new condenser design, using evaporative pre-coolers and variable-speed fans as suggested by Ref. [8]. The spraying on the condenser seems to be an original solution to improve the energetic performances as provided by Ref. [9]. The performance of the indirect evaporative cooling system (IEC) to a pre-cool air for a conventional mechanical cooling system for four cities of Iran was studied [10]. The results showed a 55\% saving in electrical energy consumption. An incorporated evaporative condenser which comprises of a system of fins, a basin of water condensates, a circuit pump and a system of drop cloud via spraying was investigated by Ref. [11]. It is concluded that the incorporated evaporative condenser improves COP to $211 \%$. The improvement of the air conditioning system performance by using the heat pipe for cooling air before entering the condenser was provided by Ref. [12]. The results showed that the heat pipe for cooling outside air before entering the condensing unit is a useful device for reducing the energy consumption in split type air conditioning systems. The fin and tube condenser that were performed using two different configurations of condenser paths ( $U$ and $\mathrm{Z}$ types) and two kinds of refrigerants (R-22 and R407C) as working fluids was investigated by Ref. [13]. The experimental and numerical results, R-22 performed better than R-407C for the Z-type path configuration. The energy flow optimization from the point where the final energy was delivered to consumers until the useful energy and energy services point was investigated by Ref. [14]. The proposed energy efficiency plan resulted in $27 \%, 54 \%$ and $10 \%$ saving in consumption, energy cost and investment cost, respectively. Air-cooled chillers that can take up around one-fourth of the total electricity consumption of an air-conditioned building were studied [15]. These findings showed how chiller manufacturers and building owners can profit from implementing energy efficient technologies for air-cooled chillers. The independent air dehumidification which provides an attractive alternative to traditional coupled air dehumidification with reduced energy use, better humidity control and indoor air quality was depicted [16]. The annual total primary energy used for independent air dehumidification is around $4.40 \mathrm{~kJ}$ per person. The Sensitivity analysis which can be used to identify important model parameters, in particular, normalized sensitivity coefficients; by allowing a one-onone comparison was carried out [17]. The improvement of the dew condensation from atmospheric vapor was studied [18]. Psychometric properties of a humid air which a linear relationship between specific humidity and dry bulb temperature (DBT) never exists were carried out Ref. [19]. A new scheme was furnished to carryout the performance analysis of partially wet fins using ADM. A notable difference in results was found compared with that values obtained from the published linear models. The utilization of heat pumps in various 
industrial technological processes as an important approach to reduce the demand of energy was investigated by Ref. [20]. A notable electricity saving was obtained. The outdoor design conditions are important parameters for energy efficiency of buildings as provided by Ref. [21]. The enhancement of COP and power saving for an air conditioning packaged unit was investigated by Ref. [22]. The results showed that COP increased by about $19.55 \%$ and the saving in the power was from $9.63 \%$ to $12.55 \%$.

In the present work, to improve the performance of splitair-conditioners by enhancing heat transfer rate in the condenser, a new design with high commercialization potential for incorporating of evaporative cooling in the condenser of split-air-conditioner is to be experimentally

\section{Experimental work and procedure}

The air conditioner, which was used in the present work, is shown diagrammatically in Fig.1, is a split-airconditioning type with $18000 \mathrm{BTU} / \mathrm{hr}$ thermal loads. Also, four pressure gauges were conducted with the air conditioning unit to record the refrigerant pressure at the inlet and the outlet of both higher and lower sides of the conditioner. Eight thermocouples were used to measure air temperatures at both inlet and outlet from the evaporator and the condenser, refrigerant temperatures at inlet and outlet of both sides of the refrigerant cycle. The relative humidity of the air which leaves the evaporator was recorded using suitable measuring equipment. The pressure dials have an accuracy of \pm 0.1 bar. The digital temperature reader has an accuracy of $\pm 0.1{ }^{0} \mathrm{C}$. Hygrometer control with an accuracy of $\pm 1 \%$ was mounted in the conditioned zone. The air conditioner was installed to condition a room having inner dimensions of $3.5 \mathrm{~m}$ length $4 \mathrm{~m}$ width, and $2.7 \mathrm{~m}$ height with four glass windows; each one has dimensions of $0.7 \mathrm{~m}$ length and $1.0 \mathrm{~m}$ width. The room contains some of educational models and one PC. The water distribution basin over the condenser is a water basin in the form of (U-shaped). Its dimensions are; $0.9 \mathrm{~m}$ length, $0.1 \mathrm{~m}$ width and $0.1 \mathrm{~m}$ height. The water basin was installed horizontally over the condenser coil such that its base is ahead of the condenser. The basin base has 100 holes that were drilled to distribute the condensation from the evaporator to go down homogenously through the condenser coil. Each hole is of $3.0 \mathrm{~mm}$ diameter and they were drilled in a staggered manner. Electrical connections have to be kept from the flowing of water droplets that may be exposed the airflow. The connections for the main equipments such as the motor of the fan and the compressor were investigated. A real air conditioner is used for the present innovation by fixing a water basin ahead the condenser. The basin dimensions are; $0.9 \mathrm{~m}$ length, $0.1 \mathrm{~m}$ width and $0.1 \mathrm{~m}$ height. Its base has 100 holes that were drilled to distribute the condensate from the evaporator to flow down homogenously through the condenser coil. Each hole is of $3.0 \mathrm{~mm}$ diameter and they were drilled in a staggered manner. The experimental test rig is mainly a vapor compression-refrigerating machine; which consists of a compressor, a condenser, an evaporator and an expansion valve. The test rig has a group of attachments to facilitate the target of the experimental work. In addition, the test rig was occupied with the necessary controlling devices.

completely insulated. The fan motor was covered with a rubber seal and a painted aluminum sheet.

The experiments were done in a range of out-door temperatures ranging $38{ }^{\circ} \mathrm{C}$ to $48{ }^{\circ} \mathrm{C}$ during hot days in summer where the recorded relative humidity ranges from $65 \%$ to $80 \%$ respectively. The runs were carried out in a laboratory in the Faculty of Industrial Education at Suez, Suez Canal University, EGYPT. The experimental tests were carried out for both dry and wet conditions. So, each experiment was done for dry conditions (dry condenser) and hence it was repeated once again for wet conditions.

From the experimental data; the pressure and temperature at inlet and outlet of each component of the cycle as well as the air temperature and its relative humidity were recorded. These data were fed to the COOLBACK soft ware to get the thermal properties that used to get the coefficient of performance of the cycle. This was carried out for both dry and evaporative conditions.

Referring to Table 1, the experimental results are provided for simultaneous dry and evaporative test runs, where the climate having a dry bulb temperature ranging from $38.0{ }^{\circ} \mathrm{C}$ to $39.7{ }^{\circ} \mathrm{C}$ and a relative humidity was almost constant at $65 \%$. The period for the test is 20 minutes and the number of test runs per day for both dry and evaporative ones are six runs during two hours for dry conditions and another two hours for evaporative conditions. 
Table 1: The observed experimental data during July 13, 2010.

\begin{tabular}{|c|c|c|c|c|}
\hline \multirow{16}{*}{ 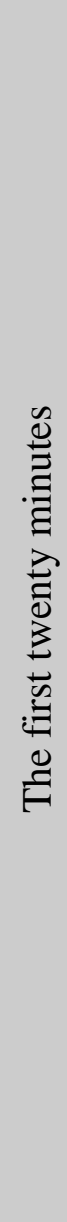 } & $\begin{array}{l}\text { Measure } \\
\text { d } \\
\text { quanti } \\
\text { ty }\end{array}$ & Unit & $\begin{array}{l}\text { Dry -test } \\
\text { at } \\
01.00 \mathrm{pm}\end{array}$ & $\begin{array}{l}\text { Evap - } \\
\text { test at } \\
03.00 \mathrm{pm}\end{array}$ \\
\hline & $T_{a m b, d b}$ & ${ }^{0} \mathrm{C}$ & 38.0 & 39.5 \\
\hline & $T_{a m b, w b}$ & ${ }^{0} \mathrm{C}$ & 28.0 & 26 \\
\hline & $T_{\text {comp }, e}$ & ${ }^{0} \mathrm{C}$ & 85.0 & 70 \\
\hline & $T_{\text {cond }, e}$ & ${ }^{0} \mathrm{C}$ & 50.0 & 42 \\
\hline & $T_{c a p, e}$ & ${ }^{0} \mathrm{C}$ & 7.2 & 4.4 \\
\hline & $T_{\text {evap }, e}$ & ${ }^{0} \mathrm{C}$ & 16.5 & 12.1 \\
\hline & $T_{\text {cond }, a, e}$ & ${ }^{0} \mathrm{C}$ & 46 & 39 \\
\hline & $T_{\text {evap }, a, i}$ & ${ }^{0} \mathrm{C}$ & 35 & 35 \\
\hline & $T_{\text {evap }, a, e}$ & ${ }^{0} \mathrm{C}$ & 12 & 10 \\
\hline & $\mathrm{i}$ & $A m p$ & 12 & 9.8 \\
\hline & $p_{\text {comp }, e}$ & psi & 352 & 295 \\
\hline & $p_{\text {cond }, e}$ & psi & 342 & 270 \\
\hline & $p_{c a p, e}$ & psi & 87 & 75 \\
\hline & $p_{\text {evap }, e}$ & psi & 75 & 66 \\
\hline & $\phi$ & $\%$ & 65 & 65 \\
\hline
\end{tabular}

The enhancement in $C O P$ and the saving in $W_{\text {comp }}$ were found as follows:

$$
\begin{array}{r}
\xi_{C O P}=\frac{C O P_{\text {evaporative }}-C O P_{d r y}}{C O P_{d r y}} \times 100 \\
\xi_{w_{c o m p}}=\frac{w_{c o m p, d y}-w_{\text {comp }, \text { evaporative }}}{w_{\text {comp }, d r y}} \times 100
\end{array}
$$

Table (4) shows the enhancement in $\zeta$ cop and the saving in $\zeta \mathrm{w}$ comp during July 13, 2010 which has a bulb temperature ranging from $38.0{ }^{0} \mathrm{C}$ to $39.7{ }^{0} \mathrm{C}$ and the relative humidity was almost constant at $65 \%$. The number of test runs is six ones during 4 hours; two for dry tests and the later two ones are for evaporative tests.
The previous experimental results that are given in Table 1 were fed to the software and the results of the soft ware for both dry and wet conditions are given in tables 3 and 4 respectively.

Table 2: Thermodynamic properties of R-22 for dry cycle (Data during July 13, 2010)

\begin{tabular}{|l|l|l|l|}
\hline \hline Property-unit & Value & Property-unit & Value \\
\hline \hline$T_{\text {evap }}\left({ }^{0} \mathrm{C}\right)$ & 6 & $T_{\text {cond }}\left({ }^{0} \mathrm{C}\right)$ & 60 \\
\hline temp of sub-cool $\left({ }^{0} \mathrm{C}\right)$ & 10 & temp of over-heat. $\left({ }^{0} \mathrm{C}\right)$ & 10 \\
\hline$q_{\text {evap }}(\mathrm{kJ} / \mathrm{kg})$ & 198.6 & $\mathrm{COP}$ & 5.53 \\
\hline$q_{\text {cond }}(\mathrm{kJ} / \mathrm{kg})$ & 234.5 & $w_{\text {comp }}(\mathrm{kJ} / \mathrm{kg})$ & 35.9 \\
\hline
\end{tabular}

Table 3: Thermodynamic properties of $\mathrm{R}-22$ for evaporative cycle (Data during July 13, 2010)

\begin{tabular}{||l|l|l|l||}
\hline Property-unit & $\begin{array}{l}\text { Val } \\
\text { ue }\end{array}$ & Property-unit & Value \\
\hline \hline$T_{\text {evap }}\left({ }^{0} \mathrm{C}\right)$ & 4 & $T_{\text {cond }}\left({ }^{0} \mathrm{C}\right)$ & 48 \\
\hline Temp of sub-cool $\left({ }^{0} \mathrm{C}\right)$ & 8 & $\begin{array}{l}\text { Temp of over-heat. } \\
\left({ }^{0} \mathrm{C}\right)\end{array}$ & 6 \\
\hline$q_{\text {evap }}(\mathrm{kJ} / \mathrm{kg})$ & $\begin{array}{l}202 . \\
7\end{array}$ & $\mathrm{COP}$ & 6.68 \\
\hline$q_{\text {cond }}(\mathrm{kJ} / \mathrm{kg})$ & 233 & $w_{\text {comp }}(\mathrm{kJ} / \mathrm{kg})$ & 30.35 \\
\hline
\end{tabular}

Table 4: the enhancement in $\zeta c o p$ and the saving in $\zeta w$ comp during July 13, 2010 for successive six experimental runs

\begin{tabular}{||c|c|c||}
\hline \hline Test run number & $\xi_{\text {COP }}(\%)$ & $\xi_{w_{\text {comp }}}(\%)$ \\
\hline \hline 1 & $16.24 \%$ & $12.1 \%$ \\
\hline 2 & $16.42 \%$ & $12.5 \%$ \\
\hline 3 & $16.50 \%$ & $12.9 \%$ \\
\hline 4 & $17.23 \%$ & $13.0 \%$ \\
\hline 5 & $17.50 \%$ & $13.2 \%$ \\
\hline 6 & $17.90 \%$ & $13.4 \%$ \\
\hline
\end{tabular}




\section{Results and discussion}

The conventional air conditioner was used in the experiment without using the water condensate; the measured values of the pressure and temperature of the refrigerant (R-22) were plotted on psychometric chart (p$\mathrm{h}$ diagram) as shown in Fig. 2. The figure indicates that in the dry case, there was no sub-cooling but in the wet case the sub-cooling occurs. Referring to Fig. 3, COP for both dry and evaporative conditions was drawn versus time, as well as the compressor work for both dry and evaporative conditions. It is clear that COP for evaporative run is much higher that that of dry run. This can be attributed to the reduction in the condenser temperature resulted from the cooling of the condenser by the evaporative condensate. The evaporative condensate (water) has high convective heat transfer coefficient which makes an efficient cooling for condenser. Also, the evaporative condensate vaporizes over the condenser surface and as a consequence one can say mass transfer accompanies the heat transfer as spatial and temporal two processes. The enhancement in COP will reduce the power consumption of the compressor.

The relative humidity has a great affect on the performance of the unit. Figure 4 shows an increase in the enhancement of the coefficient of performance versus

\section{Conclusions}

An innovative evaporative-cooled condenser for the use in small size refrigeration system was suggested and evaluated experimentally. The applications of the evaporative cooling for split-air-conditioning systems were emphasized for regions of hot weather condition. A novel design for employing direct evaporative cooling system in a split-air-conditioner was introduced. The potential of commercialization of this design is high and it could also be easily applied on existing air conditioners. The performance of air conditioner was experimentally investigated with evaporative condensate water on the condenser.

\section{References}

1- Hajidavalloo E. "Application of evaporative cooling on the condenser of window air- Conditioner". Journal of Applied Thermal Engineering, vol 27, pp 1937-43, 2007. 2- Faisal.A, Hisham. E, Mona. A, "Experimental evaluation of one, two, and three stage evaporative cooling systems" heat transfer engineering, vol 25, pp 7285, 2004.

3- Hwang Y, Radermacher R, Kopko W. "An experimental evaluation of a residential- sized evaporatively cooled condenser". International Journal of Refrigeration, vol 24, pp238-49, 2001.

4- K.A.Manske, D.T.Reindl, S.A.Klein."Evaporative condenser control in industrial refrigeration system" relative humidity. This is due to the increase in the amount of evaporative condensate which enhances the heat removal from the condenser. The increase in the evaporative condensate also reduces the compressor work as shown in Fig.

Figure 6 shows a comparison among the present experimental work and other workers of $[1,11,12$ and 22]. The dray bulb temperature was changed from 45 to $460 \mathrm{C}$ [1], from 27 to $450 \mathrm{C}$ [11], from 25 to $260 \mathrm{C}$ [12], from 27 to $350 \mathrm{C}$ [22], and from 32 to $400 \mathrm{C}$ for the present work. The improvement of the air conditioning system performance by using a heat pipe for cooling air before entering the condenser was investigated by Ref. [12]. The results show that the heat pipe for cooling outside air before entering the condensing unit is very useful device for reducing the energy consumption in the split type air conditioning system. And as a consequence it gives higher COP than present work and the works of [1, 9 and 21]. With the increase in dry bulb temperature, present work shows higher COP than [10]. The difference among the coefficient of performance in the five studies can be attributed to the differences in the dry bulb temperature and relative humidity.

The conclusions from present work can by systemized as the followings:

1-The experimental result revealed that with evaporative cooling system; the power consumption decreased and cooling capacity and coefficient of performance increased considerably.

2-The thermodynamic characteristics analysis present of the suggested system show a decrees in power consumption by about 12.1 to $20.9 \%$ and increases in the coefficient of performance by about 16.24 to $29.50 \%$.

3 - The comparison among present and previous works a notable agreement was observed.

International Journal of Refrigeration, vol 24,pp 676-691, 2001.

5- M. M. Nasr "Experimental and theoretical investigation of an innovative evaporative condenser for residential refrigerator" Renewable Energy, vol 34, pp 2447-2454, 2009.

6- J. M. Wu, X. Huang, H. Zhang. "Numerical investigation on the heat and mass transfer in a direct evaporative cooler" Applied Thermal Engineering, vol 29, pp 195-201, 2009.

7- Lu Lu .W, Yeng. C. S, Lihua. X, Shyjiang. Li, "HVAC system optimization-condenser water loop" Energy 
Conversion and Management, vol 45, pp 613 - 630, 2004.

8- F.W. Yu, K.T.Chan, "Improved condenser design and condenser-fan operation for air-cooled chillers" Applied Energy, vol 83, pp 628-648, 2006.

9- M. Youbi-Idrissi, H. Macchi-Tejeda, L. Fournaison, J. Guilpart " Numerical model of sprayed air cooled condenser coupled to refrigerating system" Energy Conversion and Management, vol 48, pp 1943-1951, 2007

10- Shahram. D, Jafar.E, Hadi. P, Maryam. K " Energy saving potential of an indirect evaporative cooler as a precooling unit for mechanical cooling systems in Iran" Energy and Buildings, vol 42 pp 2169-2176, 2010.

11- Michalis. G. V, Andronikos .E. F, Georgios. T. K, Eleftherios. D. K "Incorporated evaporative condenser. Applied Thermal Engineering" vol 27, pp 823-828, 2007. 12- Paisarn Naphon "On the performance of air conditioner with heat pipe for cooling air in the condenser" Energy Conversion and Management, vol 51, pp 2362-2366, 2010.

13- J. H. Lee, S. W. Bae, K. H. Bang, M. H. Kim " Experimental and numerical research on condenser performance for R-22 and R-407C refrigerants' International Journal of Refrigeration ,vol 25, pp 372382, 2000.

14- S. M. Sadegh Zadeh "An energy efficiency plan for the Iranian building sub-sector" Energy Policy, vol 35, pp 1164-1171,2007.

15- F.W. Yu, K.T. Chan "Economic benefits of improved condenser features for air-cooled chillers serving an air- conditioned hotel" Applied Thermal Engineering, vol 26, pp 1063-1073, 2006.

16- L.Z. Zhang "Energy performance of independent air dehumidification systems with energy recovery measures" Energy, vol 31, pp 1228 - 1242, 2006.

17- Bilal A.Qureshi, Syed M. Zubair. "A comprehensive design and rating study of evaporative coolers and condensers" International Journal of Refrigeration, vol 29, pp 659-668, 2006.

18- M. Musellia ,D. Beysens, I. Milimouk. "A comparative study of two large radiative dew water condensers" Journal of Arid Environments, vol 64, pp 54-76, 2006.

19- B. Kundu. "Approximate analytic solution for performances of wet fins with a polynomial relationship between humidity ratio and temperature" International Journal of Thermal, vol 32, pp 1-11, 2009.

20- Adnan M. Al-Harahsheh "Theoretical analyses of energy saving in a direct contact evaporative crystallization through the installation of heat pump" Desalination, vol 251, pp 47-52, 2010.

21- Mehmet. A. A, Orhan. B, Husamettin. B, Tuncay. Y "Influence of different outdoor design conditions on design cooling load and design capacities of air conditioning equipments" Energy Conversion and Management, vol 49, pp 1766-1773, 2008.

22-MED ABD-EL-HALIM MED "Performance enhancement of air conditioning with evaporative coolers" Ain shams journal of mechanical engineering, vol 1, pp 1669-1679,2008. 


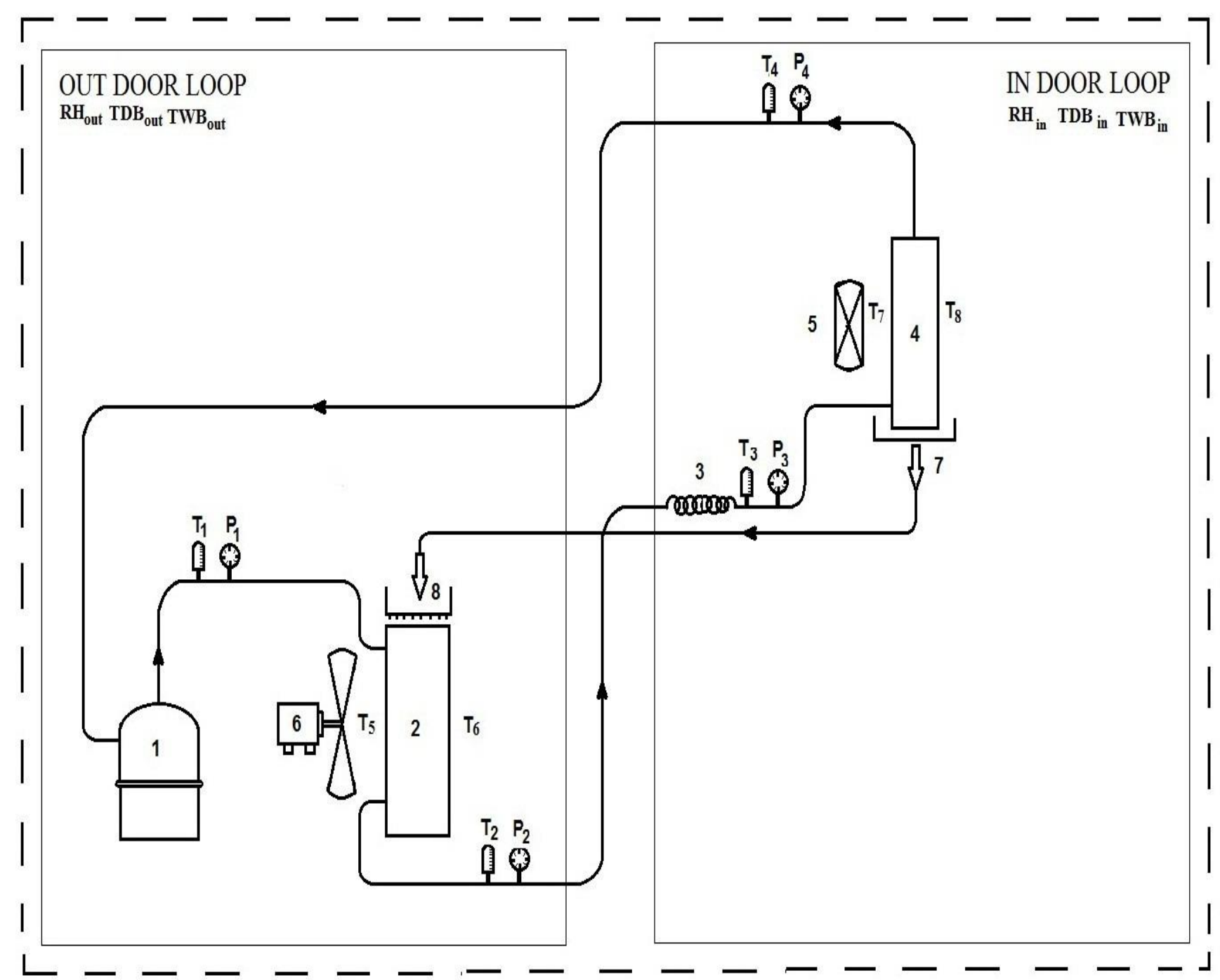

1-Compressor

2- Condenser

3- Capillary

4- Evaporator

5- Evaporator fan motor

6- Condenser fan motor

7- The water condensate from evaporator

8- The water distributed basin.

Fig 1: Experimental air conditioning unit. 


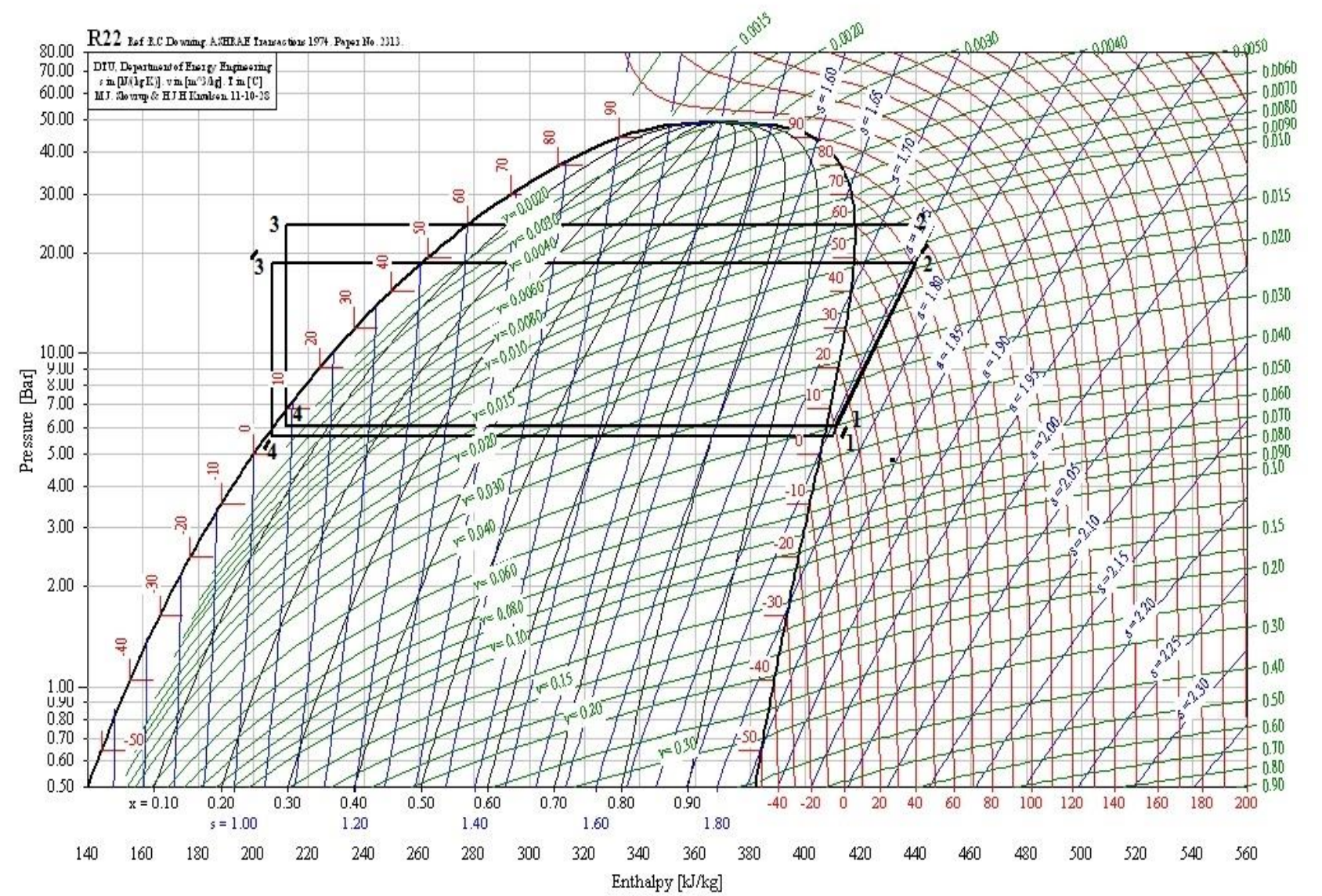

Fig 2: The p-h diagram of dry and wet experiments

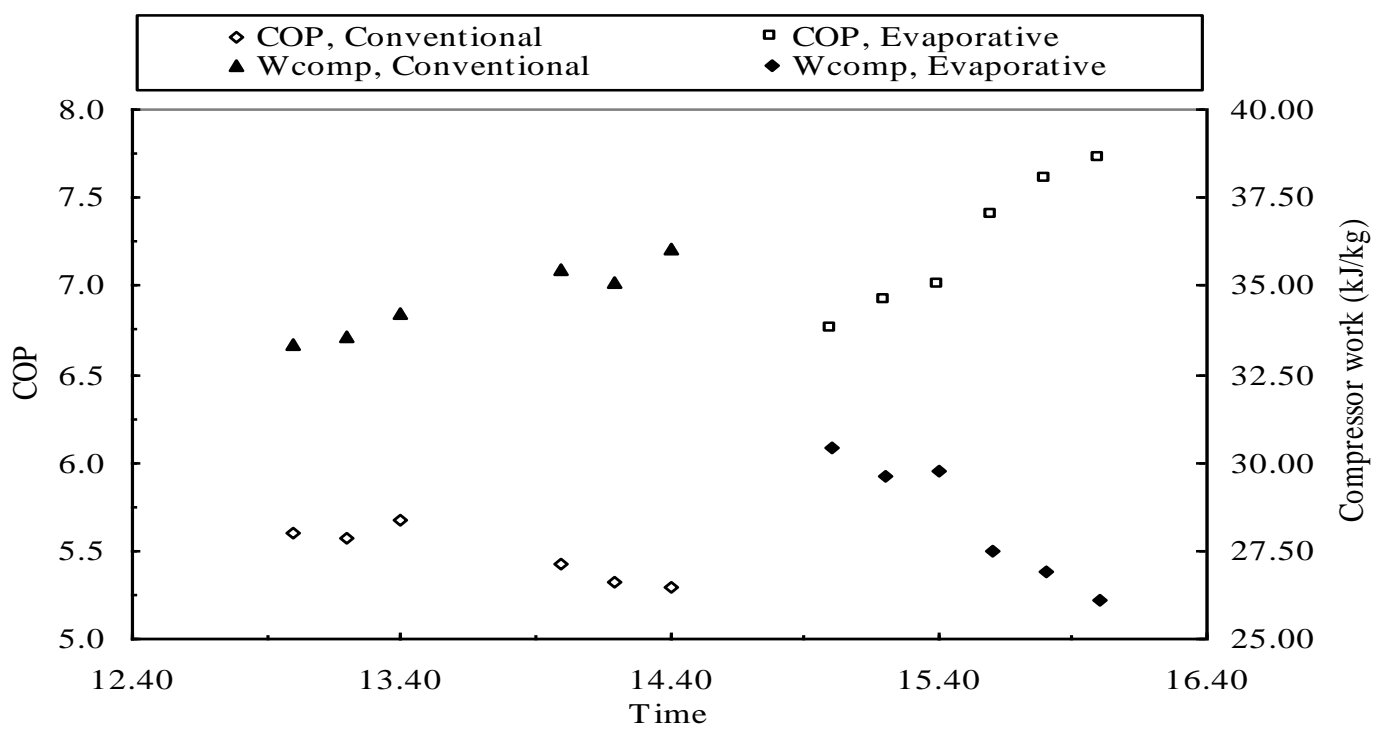

Fig 3: Variation of COP and compressor work versus time for both dry and evaporative conditions for $T_{d b}=38.4^{\circ} \mathrm{C}$ and $\phi=69.5 \%$. 


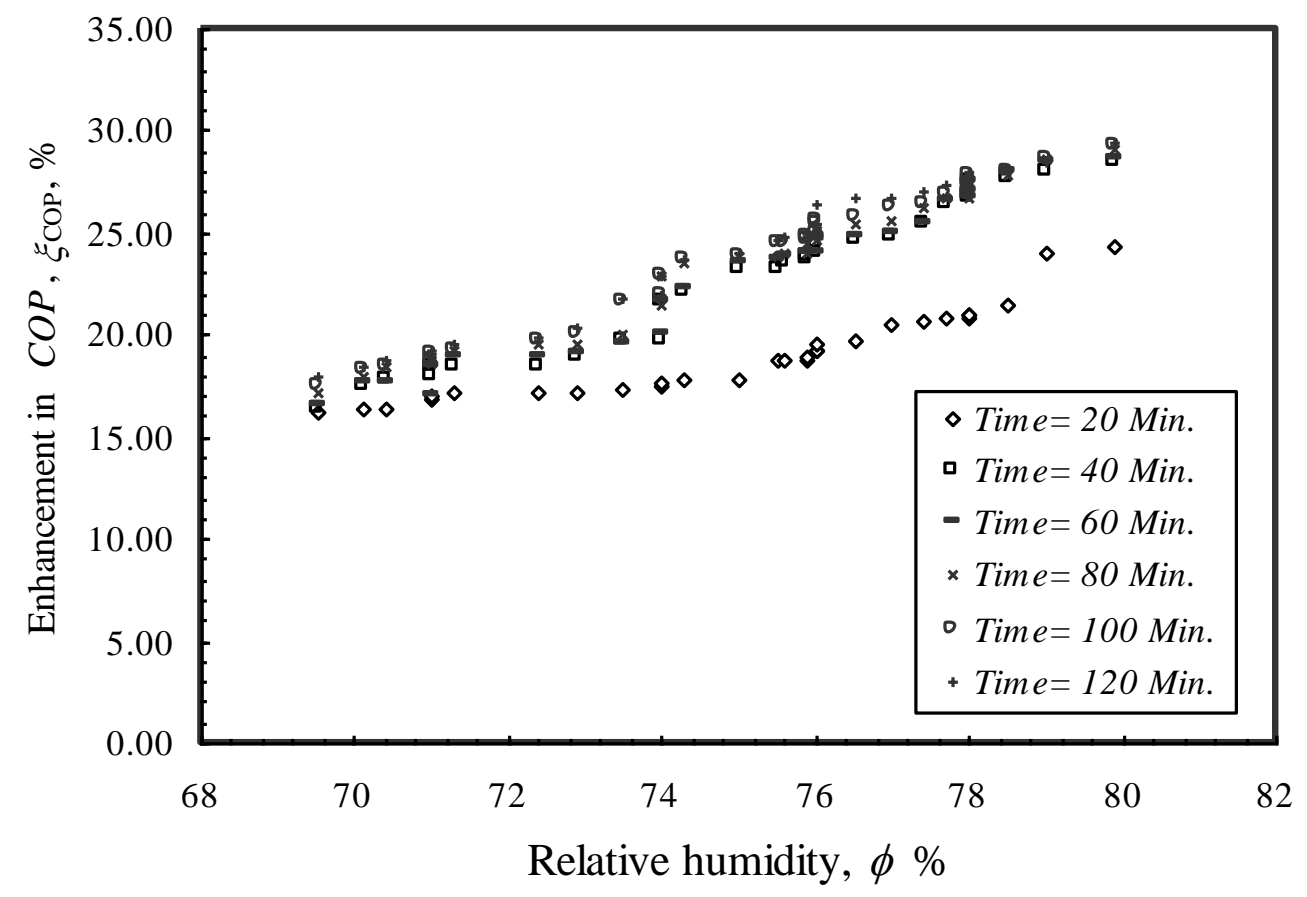

Fig 4: Variation of the enhancement of $C O P$ versus relative humidity.

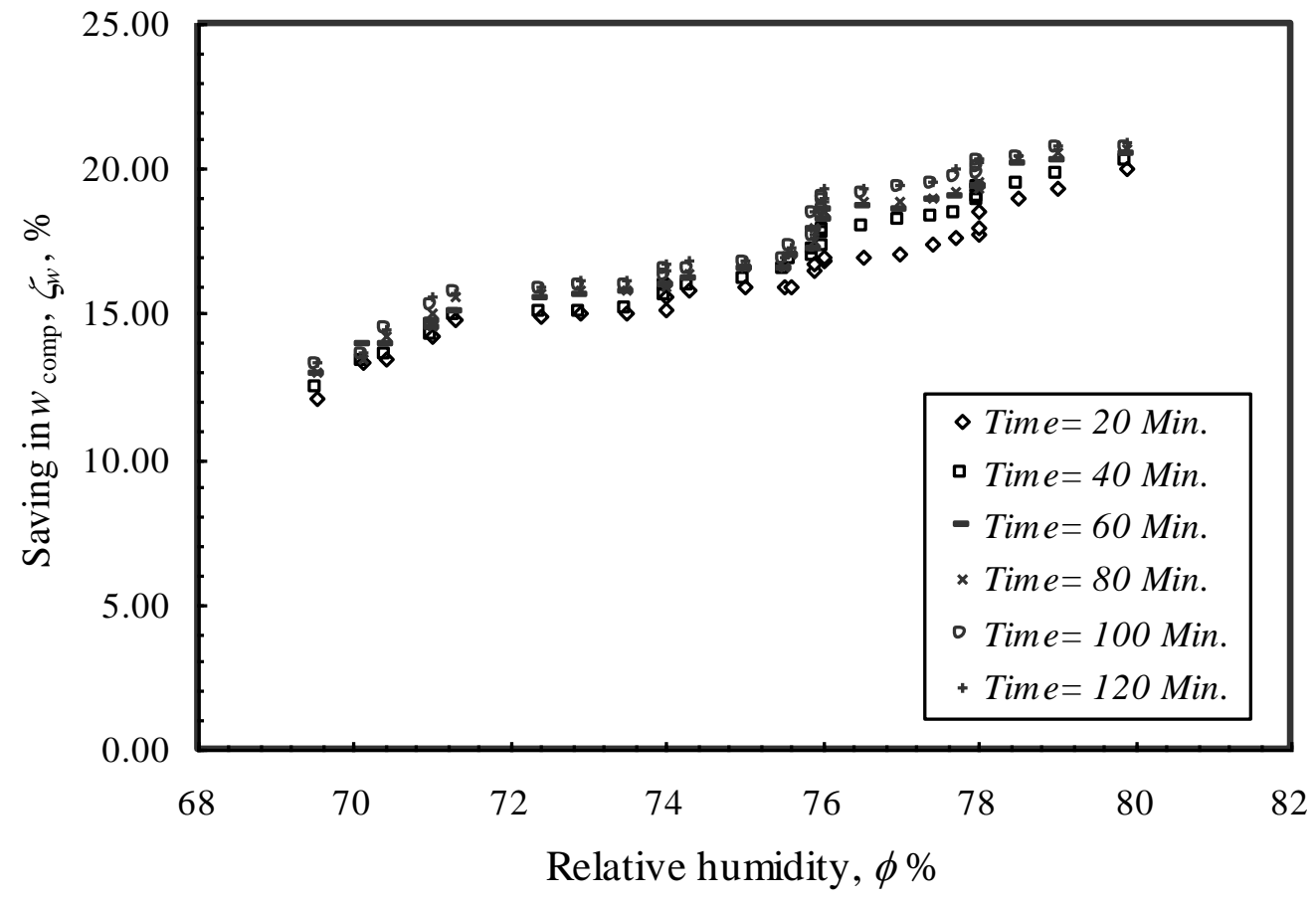

Fig 5: Variation of percentage saving in compressor work versus relative humidity. 


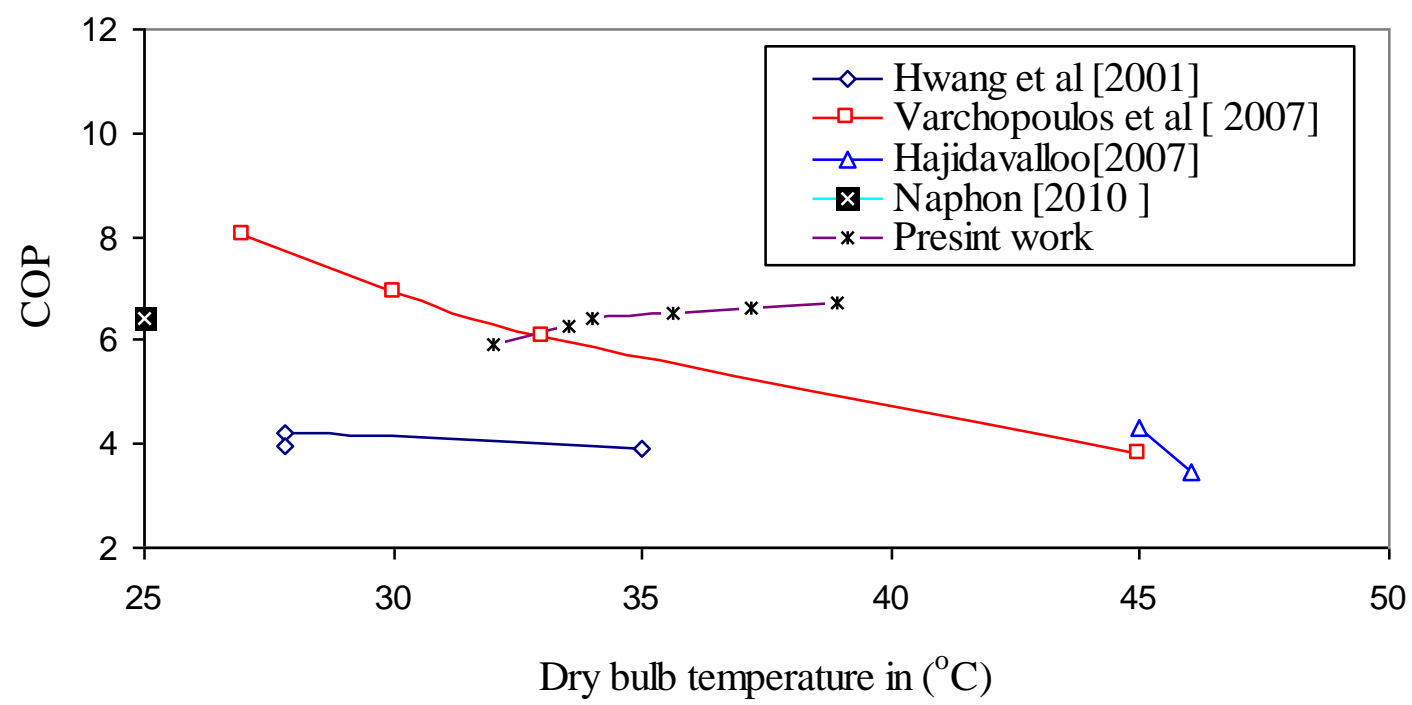

Fig 6: Comparison between present and $\operatorname{Ref}(1,3,11$, and 12). 